\title{
EVALUACIÓN DEL RIESGO DE IMPACTO AMBIENTAL DE PLAGUICIDAS EN CULTIVOS ANUALES DEL CENTRO DE SANTA FE
}

\author{
Arregui, m.c. ${ }^{1}$; Grenón, D. ${ }^{1}$; SÁnchez, D. ${ }^{1}$ \& Ghione, J. ${ }^{1}$
}

\begin{abstract}
RESUMEN
Los plaguicidas permiten alcanzar la productividad y la sustentabilidad si se manejan adecuadamente. La elaboración de indicadores permite cuantificar el impacto ambiental de un fitosanitario. El objetivo de este trabajo fue determinar el impacto ambiental de plaguicidas sobre el suelo y el agua en lotes de agricultura del centro de Santa Fe con tres indicadores: GUS, Ipest e Índice relativo de Plaguicidas. El trabajo se realizó en 25 establecimientos cuyos registros de aplicaciones en cultivos de soja, maíz y trigo se relevaron entre 2007 y 2011. Se calcularon los tres indicadores y se compararon los resultados obtenidos. El maíz fue el cultivo con mayor riesgo de impacto ambiental por el uso intensivo de atrazina. En trigo y soja, los ingredientes activos empleados tuvieron bajo impacto ambiental. El empleo de indicadores contribuye a seleccionar plaguicidas con mejor comportamiento ambiental y realizar una planificación más sustentable de los cultivos.
\end{abstract}

Palabras claves: GUS, Ipest, Índice Relativo de Plaguicidas.

\section{SUMMARY}

\section{Assessment of pesticide environmental risks in annual crops in center of Santa Fe.}

Pesticides are essential tools to achieve productivity and sustainability in agricultural crops when they are applied minimizing undesirable effects. Pesticide environmental impact is related to toxicity and time of exposure. Several indicators allow the calculation of this impact: GUS, IPEST and Relative Pesticide Index. Our aim was the evaluation of pesticide environmental impact on soil and water in agricultural fields of Central Santa Fe with those three indicators. All pesticide treatments applied in soybean, wheat and corn in 25 farms were recorded from 2007 and 2011, also with soil properties and pesticide characteristics. Indicators were calculated and the results were compared. Corn has the highest risk of pesticide contamination in soil and water, related to the frequent use of atrazine. Wheat and soybean had less environmental impact. The application of indicators may be helpful for considering the use of new active ingredients and their relationship with sustainable systems.

Key words: GUS, Ipest, Relative Pesticide Index.

${ }^{1}$ Facultad de Ciencias Agrarias, Universidad Nacional del Litoral. Kreder 2805, Esperanza, provincia de Santa Fe. Tel: (03496) 426400, int. 366. e-mail: carregui@fca.unl.edu.ar

Manuscrito recibido el 18 de octubre de 2013 y aceptado para su publicación el 10 de diciemrbe de 2013 